\title{
A rare case of acute mechanical intestinal obstruction: Colonic endometriosis
}

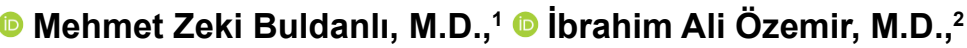 \\ 다 Oktay Yener, M.D., ${ }^{2}$ 을 Yasemin Dölek, M.D. ${ }^{3}$
}

\author{
1'Department of General Surgery, Çankırı State Hospital, Çankırı-Turkey \\ ${ }^{2}$ Department of General Surgery, İstanbul Medeniyet University, Göztepe Training and Research Hospital, İstanbul-Turkey \\ ${ }^{3}$ Department of Medical Pathology, Çankırı State Hospital, Çankırı-Turkey
}

\begin{abstract}
Endometriosis is a disease seen in women at reproductive age, characterized by extrauterine localization of endometrial tissue. Colonic endometriosis rarely causes acute mechanical intestinal obstruction (AMIO). It may also be presented with pelvic pain, dyspareunia, tenesmus, painful defecation related to the menstrual cycle. In the literature, 3-37\% of the gastrointestinal location was reported and AMIO was observed in 7-23\% of these cases. There are only few cases of mechanical obstruction related to sigmoid endometriosis mimicking colon malignancy. In this study, we aim to report a case of a 40-year-old patient with AMIO developed secondary to colonic endometriosis in light of the literature. The patient was discharged with full surgical recovery after the Hartmann procedure was performed, and the pathological diagnosis was reached as endometriosis. At the post-operative sixth-month colostomy, closure and bilateral oophorectomy were performed with the patient's will. The patient was discharged with surgical recovery and is still being regularly followed up. Endometriosis is a gynecological disease that may occur in all organ systems even though the most common location is the overs. Gastrointestinal located endometriosis should, therefore, be kept in mind in the etiology of AMIO in women at reproductive age and the related symptoms should be questioned in differential diagnosis.
\end{abstract}

Keywords: Acute mechanical intestinal obstruction; endometriosis; ileus.

\section{INTRODUCTION}

Endometriosis is a disease characterized by extrauterine localization of endometrial tissue. Environmental toxins, genetic predisposition, retrograd menstruation, stem cells, mullerianosis, coelomic metaplasia, neural growth, vasculogenesis and autoimmunity are thought to be responsible in the pathophysiology of endometriosis. ${ }^{[1,2]}$ While the major symptom of this disease is pelvic pain, dysmenorrhea, dyspareunia, dysuria, infertility and chronic pelvic pain can be observed. 20-25\% of the patients are also reported to be asymptomatic. ${ }^{[3]}$ Endometriosis is mostly seen in young women in their 30 s and 40 s. In the literature, it was shown that although endometriosis was mostly localized in ovarian tissue with $55-75 \%$, it can also be seen in fallopian tubes, anterior and posterior cul-de-sac, broad and round ligaments of the uterus, peritoneal cavity, previous operation scars, umbilicus, vagina, gastrointestinal tractus, breast tissue and even in the eyes. ${ }^{[4]}$ In the literature, $3-37 \%$ of the gastrointestinal location was reported and acute mechanical obstruction (AMIO) clinic was observed in 7-23\% of these cases. ${ }^{[5]}$ In the diagnosis of endometriosis, laboratory findings, such as CAI25, estradiol, progesterone levels; imaging methods, such as ultrasonography and magnetic resonance imaging; diagnostic laparoscopy and biopsy, are commonly used. $^{[6]}$ Treatment methods consist of hormonotherapy,

Cite this article as: Buldanlı MZ, Özemir İA, Yener O, Dölek Y. A rare case of acute mechanical intestinal obstruction: Colonic endometriosis. Ulus Travma Acil Cerrahi Derg 2020;26:148-151.

Address for correspondence: Mehmet Zeki Buldanlı, M.D.

Çankırı Devlet Hastanesi, Genel Cerrahi Kliniği, Kırkevler Mah., Kastamonu Cad., Merkez, 18100 Çankırı, Turkey.

Tel: +90 376 - 2132727 / 5003 E-mail: buldanli87@hotmail.com

Ulus Travma Acil Cerrahi Derg 2020;26(I):148-15I DOI: 10.5505/tjtes.2018.62705 Submitted: 19.07.2018 Accepted: 06.12.2018 Online: 04.04.2019

Copyright 2019 Turkish Association of Trauma and Emergency Surgery 

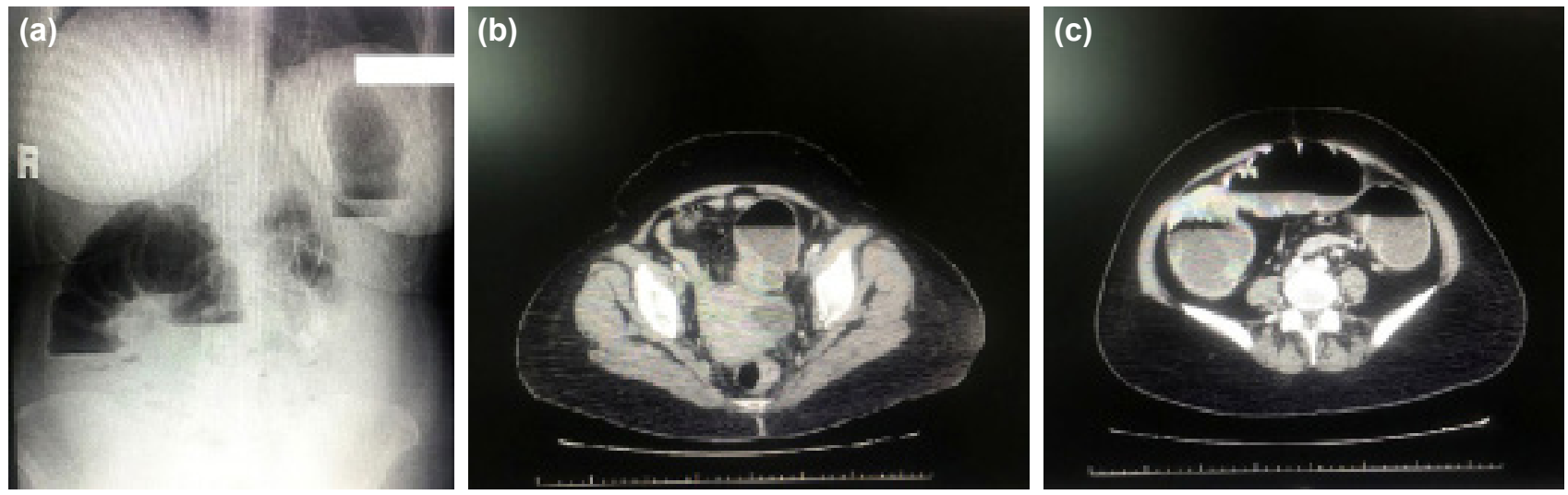

Figure 1. (a) Air-fluid levels at standing direct abdominal graphy. (b) Pelvic area at contrast-enhanced abdominal computed tomography. (c) Colonic dilatation and air-fluid levels at contrast-enhanced abdominal computed tomography

analgesic medications, neural therapy and in vitro fertilization in infertile patients. Also, in selected cases, surgery is an option. ${ }^{[7]}$

In this study, we aim to report a case of AMIO developed secondary to colonic endometriosis with the review of literature.

\section{CASE REPORT}

In this study, a 40-year-old female patient who came to emergency service with complaints of progressive diffuse abdominal pain, distension, nausea, vomiting, inability to pass gas and constipation for four days was investigated. Physical examination revealed diffuse abdominal tenderness, distension and decreased bowel sounds. Ampulla recti were found to be empty in rectal physical examination. Leukocytosis (I5.000/

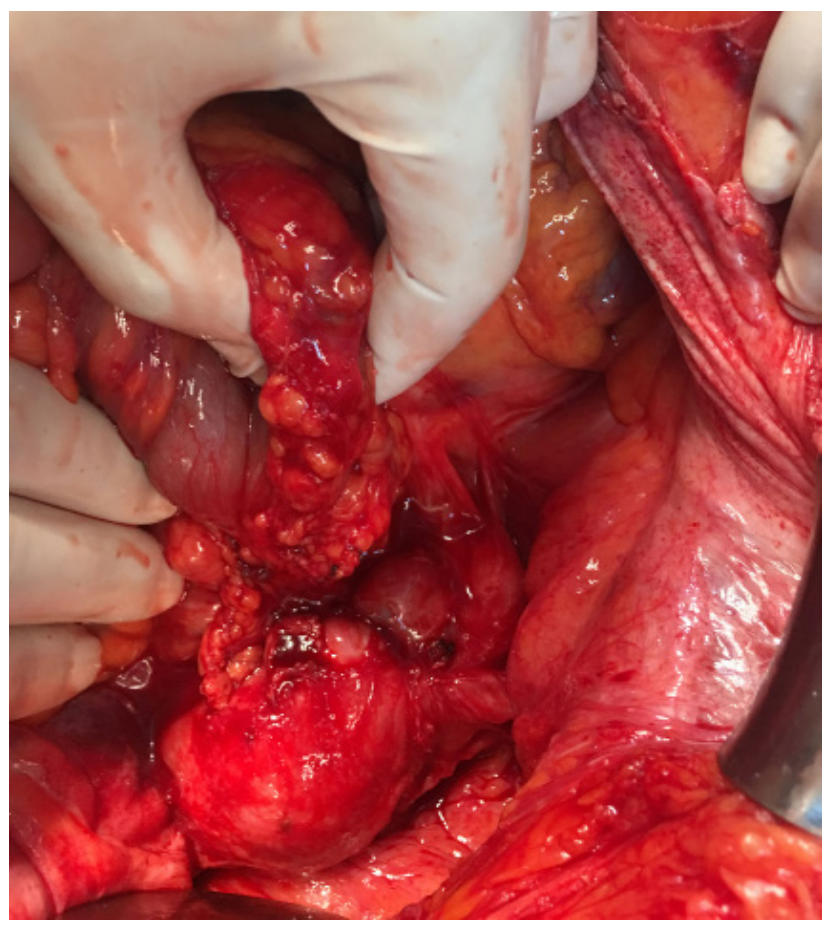

Figure 2. The pelvic area in surgical exploration. $\mu \mathrm{l})$ and high CRP levels $(15.13 \mathrm{mg} / \mathrm{dL})$ were detected. Intravenous contrast-enhanced abdominal computed tomography was performed after air-fluid levels were observed in standing direct abdominal graphy (Fig. Ia-c).

Nasogastric decompression and fluid resuscitation were administered to the patient who had AMIO clinical findings. Given that the clinical findings were not regressed despite medical treatment, the patient was operated under emergency conditions. Preoperatively small intestines were
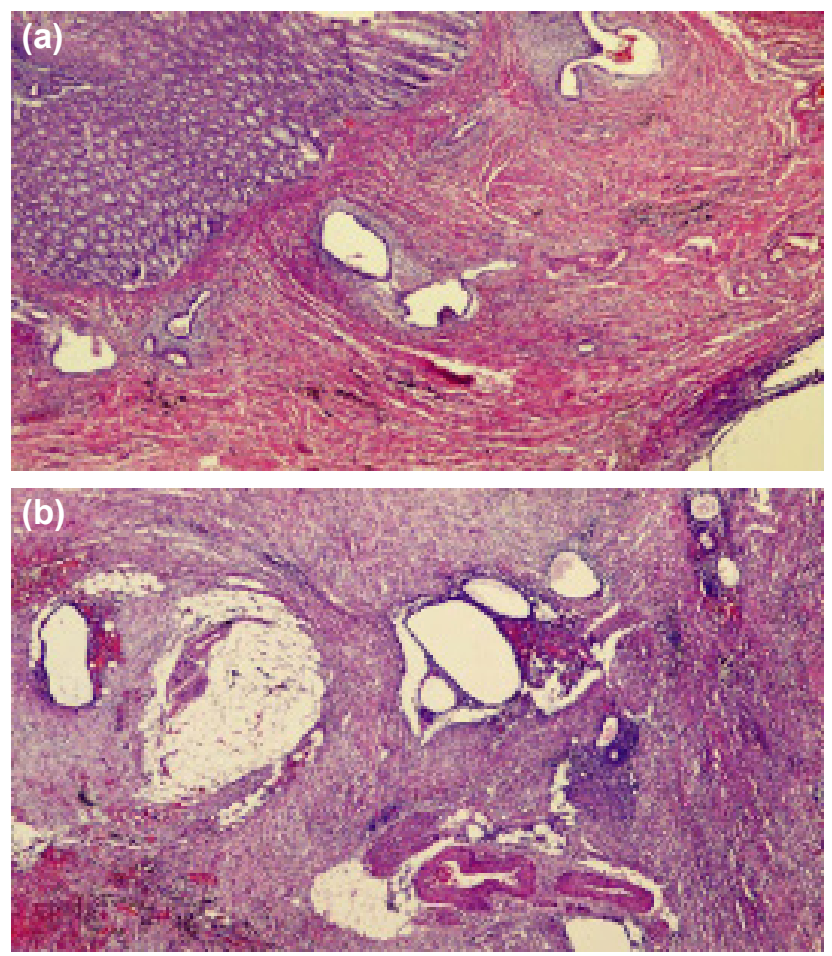

Figure 3. (a) Microscopic sections from the colon specimen showing the presence of submucosal endometrial glands and stroma in the submucosal and intramuscular layers, the colonic mucosa appears normal (stained with hematoxylin-eosin, X10). (b) Microscopic sections from the specimen showing the endometriosis involving the serosa and muscularis propria of the bowel (stained with hematoxylin-eosin, X10). 
observed to be extensively dilated and edematous. I00 cc reactional free fluid was detected and aspirated from the intra-abdominal cavity. It was observed that uterus was extensively adhered to surrounding tissues and the sigmoid colon had formed a gato with the uterus (Fig. 2). The sigmoid colon mass that was separated from the uterus was resected totally with clean surgical margins with respect to oncological principles. The procedure was terminated with the Hartmann procedure after milking to reduce the distension. Preoperative gynecological consultation was taken and no additional gynecological interventions were needed.

In the macroscopic examination of the resected material, a $3.5 \mathrm{~cm}$ cream-white mass lesion with hemorrhagic cystic spaces, extending to the serosa with a firm mucosa, which caused peritoneal surface contraction, thickened the wall and almost totally narrowed the lumen was observed. In the microscopic examination, fibrosis in serosal lipid tissue with endometrial gland and stromal tissues in the submucosa, muscularis propria and serosa with hemosiderin-laden macrophages under healthy colon mucosa was observed. The pathological diagnosis of the sigmoid colon resection material was determined to be endometriosis and reactive lymphoid hyperplasia was detected in II lymph nodes (Fig. 3a, b).

Fluid -electrolyte replacement, analgesia and antibiotherapy were administered. The oral diet was started at post-operative day 2 after the detection of viable colostomy and fecal discharge. At post-operative day 3, dyspnea, tachycardia and saturation drop were observed. No intraabdominal pathologies were detected. Cardiac and pulmonary examinations revealed atelectasis and pneumonic consolidation. Chest disease specialist consultation was taken, and the patient's complaints were relieved after medical treatment. The patient had no additional complaints and was discharged from the hospital on post-operative day 7 with full recovery. Dienogest (Visanne ${ }^{\circledR}$ ) $2 \mathrm{mg}$ pills were administered to the patient according to gynecological consultation. After medical controls, at post-operative sixth month, colostomy closure and bilateral oophorectomy were performed with the patient's will. The patient was discharged with surgical recovery and is still regularly being followed up in general surgery and gynecology clinics. Written informed consent was obtained from the patient for the publication of this case report.

\section{DISCUSSION}

Acute mechanical intestinal obstruction is one of the most common causes of acute abdomen and mostly arises from adhesions, malignancies, or intestinal herniation. It is usually presented with nausea, vomiting, colic abdominal pain and abdominal distension. ${ }^{[8]}$ Although rare, there are a few reported cases of AMIO that arise from colonic endometriosis reported in the literature, especially in young female patients, it should be kept in mind as an etiological factor. ${ }^{[9]}$
As colonic endometriosis does not have pathognomonic symptoms, such as other gastrointestinal pathologies, it can interfere with diagnoses, such as irritable bowel syndrome, inflammatory bowel diseases, ischemic colitis or even malignancy. ${ }^{[10]}$ In our case, the etiological cause was determined with histopathological examination.

It was reported in the literature that laparoscopic segmentary resection and anastomosis following decompression with endoscopic stenting could be performed to avoid stoma in cases presented with AMIO caused by colonic endometriosis. ${ }^{[1,12]}$ In our case, colonoscopy was not performed because the patient had progressing acute abdomen findings.

Although gastrointestinal localization is rare in literature, it has been reported that it is most commonly found in the rectosigmoid colon, and it is reported that women with intestinal endometriosis can be presented with severe abdominal pain due to intestinal motility. ${ }^{[13]}$ In our case, we also found that endometriosis was sigmoidal.

The clinical presentation of colonic endometriosis simulates colonic carcinomas with imaging findings, such as intestinal wall thickening and intraoperative macroscopic findings, such as adhesive mass lesions. Therefore, radical resection is required during operation. ${ }^{[14]}$ Our case was performed for the resolution of the emergency pathology, but the proximal, distal and radial surgical margins were established at appropriate width, and a perioperative gynecology consultation was performed.

In vitro fertilization (IVF) therapy is tried in appropriate female patients with infertility, but symptomatic exacerbations can be detected in this patient group according to organ or tissue in which endometriosis is placed. Seyer-Hansen and colleagues retrospectively screened the cohort of 76 patients. Nine patients had bowel-related symptoms and two patients had colonic AMIO. IVF therapy was terminated in all II patients. ${ }^{[15]}$

As a result, endometriosis is a gynecological entity capable of holding all organs, and gastrointestinal placement should be kept in mind in the etiology of AMIO, especially in female patients in the reproductive period. However, in addition to case reports identified in the relevant literature on this subject, there is a need for serials and reviews with a large number of patients.

Informed Consent: Written informed consent was obtained from the patient for the publication of the case report and the accompanying images.

Peer-review: Internally peer-reviewed.

Authorship Contributions: Concept: M.Z.B., I.A.Ö.; Design: M.Z.B., I.A.Ö.; Supervision: M.Z.B., I.A.Ö.; Fundings: M.Z.B., I.A.Ö., O.Y., Y.D.; Materials: M.Z.B., Y.D.; Data: 
M.Z.B., O.Y., Y.D.; Analysis: M.Z.B., I.A.Ö., O.Y., Y.D.; Literature search: M.Z.B., O.Y.; Writing: M.Z.B.; Critical revision: I.A.Ö., O.Y.

Conflict of Interest: None declared.

Financial Disclosure: The autors declared that this study has received no financial support.

\section{REFERENCES}

1. Giudice LC, Kao LC. Endometriosis. Lancet 2004;364:1789-99.

2. Rahmioglu N, Nyholt DR, Morris AP, Missmer SA, Montgomery GW, Zondervan KT. Genetic variants underlying risk of endometriosis: insights from meta-analysis of eight genome-wide association and replication datasets. Hum Reprod Update 2014;20:702-16. [CrossRef]

3. Bulletti C, Coccia ME, Battistoni S, Borini A. Endometriosis and infertility. J Assist Reprod Genet 2010;27:441-7. [CrossRef]

4. Giudice LC. Clinical practice. Endometriosis. N Engl J Med 2010;362:2389-98. [CrossRef]

5. Bratu D, Chicea R, Ciprian T, Beli L, Dan S, Mihetiu A, et al. A rare case of ileus caused by ileum endometriosis. Int J Surg Case Rep 2016;26:24-6. [CrossRef]

6. Tong YL, Chen Y, Zhu SY. Ileocecal endometriosis and a diagnosis dilemma: a case report and literature review. World J Gastroenterol 2013;19:3707-10. [CrossRef]

7. Liakakos T, Thomakos N, Fine PM, Dervenis C, Young RL. Peritoneal
Adhesions: Etiology, Pathophysiology, and Clinical Significance. Dig Surgery 2001;18:260-73. [CrossRef]

8. Jackson PG, Raiji MT. Evaluation and management of intestinal obstruction. Am Fam Physician 2011;83:159-65.

9. Lukovich P, Csibi N, Rigó J Jr, Bokor A. Bowel endometriosis: new challenge for gastroenterology and surgery? Three cases of endometriosis caused large bowel ileus and review of the literature. Orv Hetil 2016;157:1960-6. [CrossRef]

10. Bidarmaghz B, Shekhar A, Hendahewa R. Sigmoid endometriosis in a post-menopausal woman leading to acute large bowel obstruction: A case report. Int J Surg Case Rep 2016;28:65-7. [CrossRef]

11. Calcagno P, Viti M, Cornelli A, Galli D, D'Urbano C. Intestinal obstruction caused by endometriosis: Endoscopic stenting and expedited laparoscopic resection avoiding stoma. A case report and review of the literature. Int J Surg Case Rep 2018;44:75-7. [CrossRef]

12. Allan Z. A case of endometriosis causing acute large bowel obstruction. Int J Surg Case Rep 2018;42:247-9. [CrossRef]

13. Acar T, Acar N, Çelik SC, Ekinci N, Tarcan E, Çapkınoğlu E. Endometriosis within the sigmoid colon/extragenital endometriosis. Ulus Cerrahi Derg 2015;31:250-2. [CrossRef]

14. Varras M, Kostopanagiotou E, Katis K, Farantos Ch, Angelidou-Manika Z, Antoniou S. Endometriosis causing extensive intestinal obstruction simulating carcinoma of the sigmoid colon: a case report and review of the literature. Eur J Gynaecol Oncol 2002;23:353-7.

15. Seyer-Hansen M, Egekvist A, Forman A, Riiskjaer M. Risk of bowel obstruction during in vitro fertilization treatment of patients with deep infiltrating endometriosis. Acta Obstet Gynecol Scand 2018;97:47-52.

\section{OLGU SUNUMU - ÖZET}

\section{Nadir görülen bir akut mekanik intestinal obstrüksiyon olgusu: Kolonik endometriozis \\ Dr. Mehmet Zeki Buldanlı, ${ }^{1}$ Dr. İbrahim Ali Özemir, ${ }^{2}$ Dr. Oktay Yener, ${ }^{2}$ Dr. Yasemin Dölek ${ }^{3}$}

${ }^{1}$ Çankırı Devlet Hastanesi, Genel Cerrahi Kliniği, Çankırı

${ }^{2}$ İstanbul Medeniyet Üniversitesi, Göztepe Eğitim ve Araştırma Hastanesi, Genel Cerrahi Kliniği, İstanbul

${ }^{3}$ Çankırı Devlet Hastanesi, Tıbbi Patoloji Kliniği, Çankırı

Endometriozis, üreme çağı kadınlarda görülen, endometrium dokusunun uterus dışında yer alması ile kendini gösteren bir hastalıktır. Kolonik endometriozis menstrüal siklusla ilişkili pelvik ağrı, disparoni, tenesmus ve ağrılı dışkılama şikayetleri ile ortaya çıkabildiği gibi, nadiren akut mekanik intestinal obstrüksiyona (AMiO) da yol açabilmektedir. Literatürde \%3-37 oranında gastrointestinal yerleşim bildirilmiş olup bu olguların da \%723'ünde AMIO kliniği bildirilmiştir. Literatürde kolon malignitesini taklit eden sigmoid endometriozise bağlı az sayıda mekanik obstrüksiyon olgusu bulunmaktadır. Biz de kolonik endometriozise ikincil olarak gelişen AMiO saptanan 40 yaşındaki kadın hastayı literatür eşliğinde sunmayı amaçladık. Hartmann prosedürü uygulanan ve cerrahi tam iyileşme ile taburcu edilen hastada patolojik incelemede endometriozis tespit edildi. Ameliyat sonrası 6. ayda kolostomi kapatılması ve kendi isteğiyle bilateral ooferektomi operasyonu uygulanan hastanın takipleri devam etmektedir. Endometriozis tüm organları tutabilen jinekolojik bir hastalık olup gastrointestinal yerleşimi AMiO etiyolojisinde özellikle reprodüktif dönemdeki kadın hastalarda akılda tutulmalı ve ilişkili semptomlar sorgulanmalıdır.

Anahtar sözcükler: Akut mekanik intestinal obstrüksiyon; endometriozis; ileus.

Ulus Travma Acil Cerrahi Derg 2020;26(I): I48-15 I doi: 10.5505/tjtes.2018.62705 